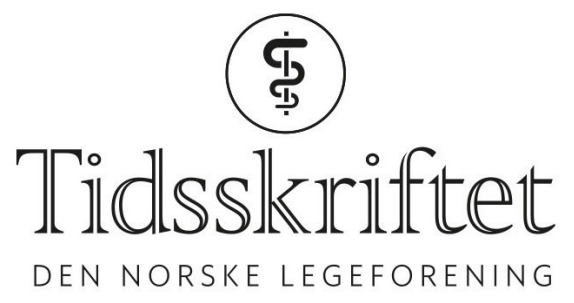

\title{
Rettelse: Det er ikke størrelsen det kommer an på
}

RETTELSE

JO RØISLIEN

Tidsskr Nor Legeforen 2018; 138: 1955 .

I Tidsskriftet nr. 20/2018 på s. 1955 skal det stå: Republikaneren Alfred Landon kom til å vinne klart over demokraten Franklin D. Roosevelt.

Vi beklager feilen, den er rettet på nett.

Publisert: 2. januar 2019. Tidsskr Nor Legeforen. DOI:10.4045/tidsskr.18.0980

(C) Tidsskrift for Den norske legeforening 2020. Lastet ned fra tidsskriftet.no 